\title{
MSW landfill leachate: formation, characterization and treatment
}

\author{
(C) Natalia O. Milyutina, ${ }^{1 *}$ Yulia A. Smyatskaya, ${ }^{2+}$ \\ Natalia A. Politaeva, ${ }^{2}$ and Pavel S. Zelenkovsky ${ }^{1}$ \\ ${ }^{1}$ Department of Environmental Geology. Institute of Earth Sciences. St. Petersburg State University, \\ Universitetskaya nab., 7-9. St. Petersburg, 199034.Russia.E-mail: milyutina_no@mail.ru \\ ${ }^{2}$ Graduate School of Hydrotechnical and Power Engineering. Peter the Great St. Petersburg Polytechnic \\ University, Polytechnic St., 29. St.-Petersburg, 195251.Russia.E-mail: smyatskaya_yua@spbstu.ru
}

\begin{abstract}
*Supervising author; ${ }^{+}$Corresponding author Keywords: MSW landfills, leachate, biogeochemical processes, leachate purification.
\end{abstract}

\begin{abstract}
The present article discusses the negative impact of municipal solid waste (MSW) landfills on the environment due to the migration of leachate formed during waste decomposition. The leachate contains an extensive list of pollutants that migrates in soils, surface and underground waters.

The article provides a review of literature regarding the main stages of leachate formation and changes in its chemical composition during the landfill's life cycle. Landfill waste undergo biogeochemical decomposition in aerobic and anaerobic conditions. At the initial stages of waste degradation, easily decomposable organic compounds oxidize leading to high values of chemical and biological oxygen demand (COD and BOD) in the formed leachate, lowering the $\mathrm{pH}$ of the medium to 4-5. This in turn leads to the transition of metal ions to the liquid phase due to an increase of their activity in acidic mediums. In anaerobic conditions, further waste degradation takes place producing carbon dioxide, methane, ammonia, mercaptans, hydrogen sulfide, organic acids and water. In the leachate formed after 10 years of landfill operation, the content of organic carbon decreases, the fraction of bioresistant components increases, the $\mathrm{pH}$ of the medium increases to 7.5-8.5, metal ions form hardly soluble compounds and sulfates are reduced to sulfides. The chemical composition of the leachate, presented in this article, demonstrates its changes depending on the stage of the landfill's life cycle.

Also, basic schemes of treatment plants for MSW leachate used in Russia and abroad are described based on a combination of traditional wastewater treatment methods (mechanical, biological and physicochemical methods).
\end{abstract}

\section{References}

[1] O.M. Guman, I.A. Dolinina Hydrogeochemical model of the MSW landfill. News of the Ural State Mining University. 2003. No.18. P.262-273. (russian)

[2] N.S. Al'-Akhval', E.G. Semin. Assessment of the impact of municipal solid waste on environmental pollution (on example Yemen). Scientific and technical statements of SPbSPU. 2010. No.2. P.209-215. (russian)

[3] T.V. Ovchinnikova, T.V. Ashikhmina, V.I. Fedyanin. The impact of solid municipal and industrial waste landfills on the state of the environment. Bulletin of VSTU. 2008. Vol.4. No.6. P.14-17. (russian)

[4] S. Mukherjee, S. Mukhopadhyay, M.A. Hashim, B. Sen Gupta. Contemporary environmental issues of landfill leachate: assessment and remedies. Critical Reviews in Environmental Science and Technology. 2014. Vol.45. No.5. P.472-590.

[5] S.V. Dubrova, I.I. Podlipskiy, V.V. Kurilenko, W. Siabato. Functional city zoning. Environmental assessment of eco-geological substance migration flows. Environmental Pollution. 2015. Vol.197. P.165-172.

[6] I.I. Podlipskiy. Ecological and geological assessment of the territory of MSW landfills. Lambert Acad. Publ. 2015. 200p. (russian)

[7] V.V. Kurilenko, I.I. Podlipskiy, N.G. Osmolovskaya. Ecological, geological and biogeochemical assessment of the impact of solid waste landfills on the environment. Ecology and industry of Russia. 2012. No.11. P.28-32. (russian)

[8] I.N. Buzina, V.K. Puzik. Soil condition and environmental assessment around the solid waste landfill. Bulletin of BSAA. 2014. No.3. P.102-106. (russian) 
[9] V. Popovych, J. Telak, O. Telak et al. Migration of hazardous components of municipal landfill leachates into the environment. J. of Ecological Engineering. 2020. Vol.21. P.52-62.

[10] S.V. Solsky, D.P. Samofalov. The rationale for closed water circulation systems in the arrangement of MSW landfills. News of the VNIIG. 2003. Vol.242. P.175-185. (russian)

[11] G. Denafas, T. Ruzgas, D. Martuzevicius et al. Seasonal variation of municipal solid waste generation and composition in four East European cities. Resources, Conservation and Recycling. 2014. Vol.89. P.22-30.

[12] Ya.I. Vaisman. Waste management. Wastewater and biogas of solid waste landfills. Permian: PNRPU Publ. 2012. 259p. (russian)

[13] V.S. Putilina, I.V. Galitskaya, T.I. Yuganova. The effect of organic matter on the migration of heavy metals in areas of landfills. Ekologiya. Ecology. Analytical reviews of world literature. 2005. Vol.76. P.1-100. (russian)

[14] T. Christensen, R. Cossu, R. Stiegmann. Landfilling of waste: Leachate. Boca Raton: CRC Press. 2019. 540p.

[15] L.P. Gribanova. Landfills processes. MSW. 2006. No.7. P.4-7. (russian)

[16] M.I. Al-Wabel, W.S. Al-Yehya, A.S. Al-Farraj, S.E. El-Maghraby. Characteristics of landfill leachates and bio-solids of municipal solid waste (MSW) in Riyadh City, Saudi Arabia. J. of the Saudi Society of Agricultural Sciences. 2011. Vol.10. No.2. P.65-70.

[17] H. Luo, Y. Zeng, Y. Cheng, D. He, X. Pan. Recent advances in municipal landfill leachate: A review focusing on its characteristics, treatment, and toxicity assessment. Science of the Total Environment. 2019. Vol.703. P.135468.

[18] P.M. Fedorov, E.Yu. Negulyaeva, E.R. Pokrovskaya. Research and modeling of biochemical processes occurring at solid waste landfills. Integrated processing of municipal solid waste - the most advanced technology: collection of works. SPb. 2001. P.62-70. (russian)

[19] L.M. Chu, K.C. Cheung, M.H. Wong. Variations in the chemical properties of landfill leachate. Environmental Management. 1994. Vol.18. P.105-117.

[20] S. Aziz, M. Bashir, H. Aziz, A. Mojiri, S. Abu Amr, Y. Maulood. Statistical analysis of municipal solid waste landfill leachate characteristics in different countries. Zanco J. of Pure and Applied Sciences. 2018. Vol.30. No.6. P.85-96.

[21] Ya.I. Vaisman. Physicochemical methods for protecting the biosphere. Purification of landfills leachate: a training manual. Permian: PNRPU Publ. 2005. 197p. (russian)

[22] T.V. Voronkova, Ya.I. Vaisman, S.Yu. Chudinov. Recycling of leachate at MSW landfills. Bulletin of PNRPU. Urban studies. 2012. No.3. P.83-91. (russian)

[23] R. He, D. Shen, J. Wang et al. Biological degradation of MSW in a methanogenic reactor using treated leachate recirculation. Process Biochemistry. 2005. Vol.40. No.12. P.3660-3666.

[24] H.D. Robinson, P.J. Morris. The treatment of municipal landfill leachate. Water Research. 1999. Vol.17. No.11. P.56-61.

[25] A.V. Malysheva. Purification of landfill leachate: membrane technology. MSW. 2011. No.6. P.32-33. (russian)

[26] A.A. Povorov, V.F. Pavlova, N.A. Shinenkova, O.Yu. Logunov. The technology of purification of drainage landfill waters. $M S W$. 2009. No.4. P.26-27. (russian)

[27] J. Wiszniowski, D. Robert, J. Surmacz-Gorska, K. Miksch, J.V. Weber. Landfill leachate treatment methods: A review. Environmental Chemistry Letters. 2015. Vol.4. No.1. P.51-61.

[28] Z. Salem, K. Hamouri, R. Djemaa, K. Allia. Evalution of landfill leachate pollution and treatment. Desalination. 2008. Vol.220. P.108-114.

[29] Z. Youcai. Pollution control technology for leachate from municipal solid waste. Oxford: Elsevier Ltd. 2018. $564 \mathrm{p}$.

[30] M.V. Solodovnik. Special aspects of the formation and treatment of drainage water of MSW landfills. Water purification. Water treatment. Water supply. 2009. No.4. P.10-14. (russian)

[31] M.C. Drouiche, K. Moussaceb, E. Joussein, J.C. Bollinger. Stabilization/solidification by hydraulic binders of metal elements from landfill leachate. Nova Biotechnologica et Chimica. 2019. Vol.18. No.1. P.72-83.

[32] Patent RUS №2460704/ 10.09.12. I.M. Ostrovkin, P.I. Ostrovkin. The method of utilization of the MSW landfill leachate and ash. 7p. (russian)

[33] N.O. Milyutina, N.A. Averianova, N.A. Politaeva. Studying the properties of cementation product obtained from landfill leachate. Ecological monitoring of hazardous industrial facilities: current achievements, prospects and ensuring environmental safety of the population: collection of works. Saratov. 2019. P.188-191. (russian) 